\title{
Komposisi Larva Ikan pada Ekosistem Lamun di Perairan Jepara Jawa Tengah
}

\author{
Muhamad Ravian Wiraputra*, Suryono, Hadi Endrawati \\ Departemen IImu Kelautan, Fakultas Perikanan dan IImu Kelautan, Universitas Diponegoro \\ JI. Prof. H. Soedarto S.H, Tembalang, Semarang, Jawa Tengah 50275 Indonesia \\ ${ }^{*}$ Corresponding author, email : wiraputra1997@gmail.com
}

\begin{abstract}
ABSTRAK: Larva merupakan fase pertumbuhan awal pada ikan, pada fase tersebut ikan-ikan membutuhkan tempat untuk berlindung dan mencari makanan. Ekosistem lamun sangat mendukung keberlangsungan hidup ikan, fungsi ekologis lamun sebagai daerah memijah, daerah asuhan serta tempat mencari makan bagi ikan. Tujuan penelitian ini untuk mengetahui kehadiran, serta mengetahui hubungan antara kelimpahan larva ikan dan lamun di Perairan Prawean dan Blebak, Kabupaten Jepara. Metode yang digunakan dalam penelitian ini adalah metode deskriptif dan penentuan lokasi sampling menggunakan purposive sampling methode. Penelitian ini dilakukan pada dua lokasi yang berbeda dengan masing-masing lokasi memiliki 2 stasiun, pada setiap stasiun memiliki 3 stasiun. Pengambilan sampel larva ikan dilakukan dengan menggunakan larva net $(P=0,9 \mathrm{~m} ; \mathrm{L}: 0,6 \mathrm{~m})$ dengan ukuran mata jaring $800 \mu \mathrm{m}$. Sampel yang didapat kemudian disortir dan diidentifikasi menggunakan literatur. Hasil penelitian ini ditemukan Nemipteridae, Lutjanidae, Ambassidae, Sphyraenidae, Bothidae, Clupeidae, Chanidae, Monacanthidae. Famili larva ikan yang dominan adalah Nemipteridae. Nilai indeks keanekaragaman dari empat stasiun termasuk dalam kategori rendah-sedang $(0,92-1,50)$. Nilai indeks keanekaragaman dari empat stasiun termasuk dalam kategori sedang-tinggi $(0,61-1,00)$. Kisaran nilai indeks dominasi larva ikan dari empat stasiun menunjukan tidak adanya famili yang mendominasi $(0,23-0,54)$.
\end{abstract}

Kata kunci: Kelimpahan; Larva Ikan; Lamun; Perairan Prawean; Perairan Blebak.

\section{The Composition of Fish Larvae on Seagrass Beds Jepara Coastal Waters Centra Java}

ABSTRACT: Larvae are an early growth phase in fish, in that phase fish need a place to take shelter and find food. Seagrass ecosystem strongly supports the survival of fish, the ecological functions of seagrass as a clusters area, an area of care and a place to eat for fish. The purpose of this research is to know the presence, and know the relationship between the abundance of fish larvae and seagrass in Prawean waters and Blebak, Jepara regency. The method used in this research is the descriptive method and determination of location sampling using purposive sampling Methode. The research was conducted on two different locations with each location having 2 stations, at each station having 3 substations. Sampling of fish larvae is done using the net larva $(P=0.9 \mathrm{~m} ; \mathrm{L}: 0,6 \mathrm{~m})$ with mesh eye size $800 \mu \mathrm{m}$. The obtained samples were then sorted and identified using literature. The results of this study were found in the larvae of 8 families Nemipteridae, Lutjanidae, Ambassidae, Sphyraenidae, Bothidae, Clupeidae, Chanidae, Monacanthidae. The family of fish larvae most commonly found are Nemipteridae. The value of the diversity index of the four stations is included in the low-medium category (0.92 - 1.50). The value of the diversity index of four stations is included in the medium-high category (0.61 - 1.00). The value of the index of the dominance of the fish from the four stations indicates that there is no dominant family $(0.23-0.54)$.

Keywords: Abundance; Fish Larvae; Seagrasses; Prawean Waters; Blebak Waters

\section{PENDAHULUAN}

Ekosistem lamun memiliki fungsi ekologis sebagai daerah memijah (spawning ground), daerah asuhan (nursery ground), dan daerah mencari makan (feeding ground) bagi ikan (Rinaldi et 
al., 2018). Secara ekologis, pada fase larva ikan banyak ditemukan pada ekosistem lamun sebagai tempat mencari makan, tempat berlindung dari predator (Danovaro et al., 2002). Kondisi ini memungkinkan daerah lamun dapat menjadi daerah pembesaran dan perlindungan bagi beberapa biota laut termasuk larva ikan (Riniatsih, 2016). Letak yang berdekatan dengan ekosistem pantai tropis, ekosistem lamun tidak terisolisasi atau berdiri sendiri tetapi berinteraksi dengan ekosistem disekitarnya (Nybaken, 1992).

Pantai Prawean merupakan pantai yang banyak di datangi oleh nelayan sebagai tempat untuk menangkap ikan serta tempat berlabuhnya perahu-perahu nelayan serta perahu warga desa yang digunakan sebagai alat transportasi wisata. Pantai blebak merupakan pantai yang berpotensi sebagai ekowisata di daerah Jepara, pantai ini ramai didatangi oleh wisatawan untuk menikmati keasrian pantainya (Hidayaturrohmah et al., 2018). Kondisi tersebut diduga akan berpengaruh pada pertumbuhan lamun, oleh sebab itu perlu dilakukan penelitian mengenai kelimpahan larva ikan yang didasarkan pada perbedaan kondisi kerapatan padang lamun di masing-masing lokasi. Kerapatan lamun di suatu perairan dapat mempengaruhi kelimpahan larva ikan, semakin rapat tegakan lamun maka kelimpahan larva ikan semakin tinggi. Mengingat hal tersebut, perlu dilakukan penelitian mengenai kelimpahan larva ikan pada ekosistem padang lamun di Perairan Pantai Prawean dan Pantai Blebak guna mengetahui kelimpahan larva ikan pada masing-masing lokasi. Tujuan penelitian ini untuk mengetahui kehadiran, serta mengetahui hubungan antara kelimpahan larva ikan dan lamun di Perairan Prawean dan Blebak. Analisis mengenai larva ikan yang terdapat pada ekosistem padang lamun dapat dikatakan sebagai suatu bentuk tinjauan dari fase awal daur dari kehidupan suatu onganisme laut dalam hal tersebut larva ikan (Saraswati et al., 2016). Tutupan padang lamun di suatu perairan menjadi salah satu faktor bagi pertumbuhan larva ikan, seperti pada tutupan lamun yang jarang larva ikan yang berasosiasi memiliki tubuh yang cenderung sangat kecil dan jumlahnya sedikit (Rappe, 2010).

\section{MATERI DAN METODE}

Materi penelitian yang digunakan dalam penelitian ini adalah sampel larva ikan pada padang lamun yang berbeda di perairan Prawean dan Blebak, Kabupaten Jepara. Selain materi larva ikan diatas, \% penutupan lamun dan beberapa parameter hidrofisik perairan juga diukur, antara lain suhu, salinitas, kecerahan, kecepatan arus, oksigen terlarut, kandungan bahan organik dan nutrien di perairan. Metode yang digunakan dalam penelitian ini adalah metode daskriptif eksploratif, yaitu metode penelitian yang dilakukan dengan tujuan membuat pencandraan secara sistematis, faktual dan akurat tehadap kejadian populasi tertentu pada suatu wilayah tertentu (Suryabrata, 1992). Pada masing-masing lokasi penelitian sampel larva ikan ditangkap pada pagi hari dengan interval sampling antar lokasi berbeda satu hari, setiap lokasi memiliki dua stasiun dengan masing-masing stasiun memiliki tiga substasiun. Penentuan lokasi sampling dilakukan dengan metode pertimbangan (Purposive Sampling Methods). Hasil tangkapan berupa larva ikan dimasukkan ke dalam botol sampel yang telah diisi formalin $4 \%$ dengan volume $100 \mathrm{ml}$. Selanjutnya sampel dibawa ke Laboratorium Biologi Jurusan IImu Kelautan FPIK Undip untuk dilakukan sortir dan identifikasi. Identifikasi sampel larva ikan dilakukan berdasarkan ketentuan Leis dan Rennis (1983) sebagai acuan. Selama pengambilan sampel juga dilakukan pengukuran parameter hidrooseanografi (suhu, salinitas, kecepatan arus, kecerahan, oksigen terlarut dan data pendukung lainnya (meliputi \% penutupan lamun). Data yang digunakan untuk analisa data meliputi komposisi jenis dan kelimpahan larva ikan serta korelasi hubungan kelimpahan larva ikan dengan kerapatan lamun. Korelasi hubungan kelimpahan larva ikan dengan kerapatan lamun digitung menggunakan rumus struktur komunitas larva ikan dihitung dengan melihat indeks keanekaragaman, indeks keseragaman dan dominasi jenis. Perhitungan hubungan kelimpahan larva ikan dan kerapatan lamun dihitung menggunakan rumus:

$$
r=\frac{n \sum x y-\left(\sum x\right)\left(\sum y\right)}{\sqrt{\left\{\mathrm{n} \sum x^{2}-\left(\mathrm{n} \sum x\right)^{2}\right\}\left\{\mathrm{n} \sum x^{2}-\left(\sum y\right)^{2}\right\}}}
$$

Keterangan: $\mathrm{n}=$ banyaknya pasangan data $\mathrm{x}$ dan $\mathrm{y} ; \Sigma \mathrm{x}=$ Total jumlah variabel $\mathrm{x} ; \Sigma \mathrm{y}=$ Total jumlah variabel $\mathrm{y} ; \Sigma \mathrm{x}^{2}=$ Kuadrat dari total jumlah variabel $\mathrm{x} ; \Sigma \mathrm{y}^{2}=\quad$ Kuadrat dari total jumlah variabel $\mathrm{y} ; \quad \sum \mathrm{xy}=$ Hasil perkalian dari total jumlah variabel $x$ dan variabel $y$ 


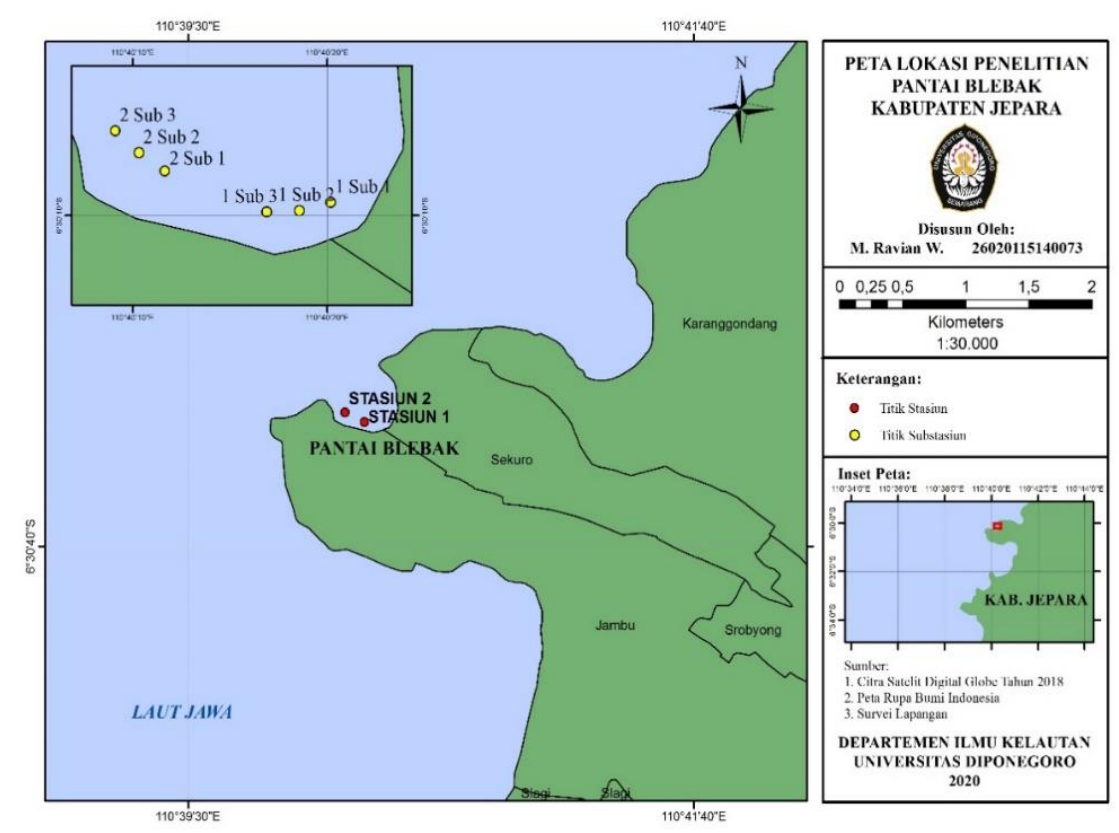

Gambar 1. Lokasi Penelitian di Perairan Blebak, Kab. Jepara

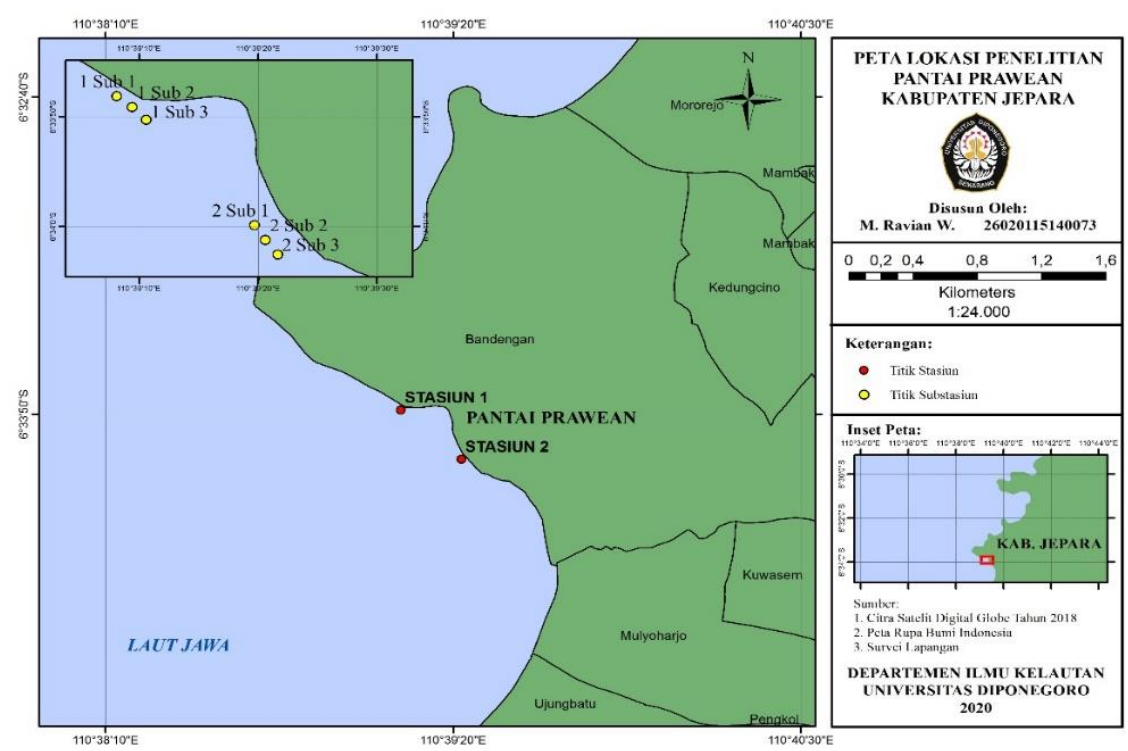

Gambar 2. Lokasi Penelitian di Perairan Prawean, Kab. Jepara

\section{HASIL DAN PEMBAHASAN}

Jumlah total larva ikan yang tertangkap selama penelitian terdapat sebanyak 207 ekor dari 8 famili. Hasil buku identifikasi menunjukan famili yang didapat diantaranya Nemipteridae, Lutjanidae, Ambassidae, Sphyraenidae, Bothidae, Clupeidae, Chanidae, dan Monacanthidae. Komposisi larva ikan tersebut dapat dilihat pada (Tabel 1). Kelimpahan larva ikan di lokasi perairan pantai Prawean memiliki hasil kelimpahan $1074 \mathrm{ind} / \mathrm{m}^{3}$ (Stasiun 1) dan $1537 \mathrm{ind} / \mathrm{m}^{3}$ (pada pengambilan sampel stasiun ke 2). Pada lokasi penelitian Pantai Blebak terdapat hasil kelimpahan $648 \mathrm{ind} / \mathrm{m}^{3}$ (pada pengambilan sampel stasiun ke 1) dan sebanyak $574 \mathrm{ind} / \mathrm{m}^{3}$ (pada pengambilan sampel stasiun ke 2). Kelimpahan larva ikan pada setiap lokasi dapat dilihat pada (Gambar 3).

Nilai persentase (\%) penutupan selama penelitian dari masing-masing lokasi pengamatan menunjukan kisaran antara 1,13-3,21\% untuk jenis lamun Enhalus acoroides, 10,22-13,44\% untuk jenis lamun Thalassia hemprichii, 9,46-14,73\% untuk jenis lamun Cymodocea serrulata, 4,73- 
9,46\% untuk jenis lamun Cymodocea rotundata, dan, 3,78-5,11\% untuk jenis lamun Halodule uninervis, selengkapnya disajikan pada (Tabel 2). Hasil perhitungan \% penutupan lamun menunjukkan perairan Prawean mempunyai \% Penutupan yang lebih tinggi dibandingkan \% penutupan lamun pada lokasi penelitian perairan Pantai Blebak.

Hasil kelimpahan larva ikan yang didapat selamat penelitian pada lokasi perairan Pantai Prawean berjumlah 7 famili dan pada lokasi perairan Pantai Blebak terdapat 5 famili. Diantara ke 2 lokasi tersebut terdapat kesamaan jenis famili yaitu Nemipteridae, Lutjanidae, Ambassidae, dan Monacnthidae. Seperti pada tabel 3 famili Sphyraenidae hanya ditemukan di perairan Pantai Blebak, sedangkan famili dari Bothidae, Clupeidae, dan Chanidae hanya ditemukan pada perairan Pantai Prawean. Total famili ikan yang ditemukan selama penelitian terdapat 8 famili. Famili ikan yang diperoleh selama penelitian menunjukan jenis ikan yang memiliki habitat asli bukan di padang lamun, melainkan jenis-jenis ikan yang bermigrasi di padang lamun untuk mencari makan dan sebagai tempat berlindung dari predator, hal ini diperkuat oleh penelitian yang dilakukan oleh Rappe (2010), Syukur et al. (2014) dan Saraswati et al. (2016), bahwa famili ikan Nemipteridae, Lutjanidae, Ambassidae, Sphyraenidae, Bothidae, Clupeidae, Monacnthidae dan Chanidae merupakan ikan yang berasosiasi pada padang lamun.

Hasil pengamatan didominasi oleh famili ikan yang biasa ditemukan di daerah terumbu karang atau bisa dikatakan sebagai ikan karang sejati, ikan-ikan karang tersebut yang didapatkan diantaranya Nemipteridae, Lutjanidae, Ambassidae, Monacanthidae, dan Sphyraenidae. Lokasi pengamatan diketahui berdekatan dengan terumbu karang, maka diduga ada keterkaitan antara ekosistem padang lamun dan ekosistem terumbu karang dalam hal migrasi ikan, hal ini sesuai dengan hasil penelitian yang dilakukan oleh Smith-Vaniz dan Rose (2012). Ikan yang ditemukan pada areal padang lamun erat kaitannya dengan keragaman jenis makanan ikan yang ada pada padang lamun (Kiswara et al., 1994).

Nilai indeks keanekaragaman yang berada pada setiap lokasi penelitian menunjukkan bahwa banyak faktor yang berpengaruh pada jumlah populasi ikan, hal ini diduga karena adanya perbedaan presentase penutupan lamun, atau faktor-faktor hidro-oseanografi yang berbeda di setiap lokasi penelitian (Olli, 2003). Nilai indeks keanekaragaman (H') pada Pantai Prawean memiliki hasil 0,9248 (Keanekaragaman sedang) pada stasiun 1 dan 1,5022 (keanekaragaman sedang) pada stasiun 2, pada Pantai Blebak stasiun 1 memiliki hasil 1,031 (keanekaragaman

Tabel 1. Kehadiran Larva Ikan

\begin{tabular}{lcc}
\hline \multirow{2}{*}{ Famili lkan } & \multicolumn{2}{c}{ Lokasi } \\
\cline { 2 - 3 } Nemipteridae & Pantai Prawean & Pantai Blebak \\
Lutjanidae & + & + \\
Ambassidae & + & + \\
Sphyraenidae & + & + \\
Bothidae & - & + \\
Clupeidae & + & - \\
Chanidae & + & - \\
Monacanthidae & + & - \\
\hline
\end{tabular}

Tabel 2. Rata-rata \% Penutupan Lamun di Lokasi Penelitian

\begin{tabular}{cccccc}
\hline Sub & \multicolumn{5}{c}{ Penutupan Spesies lamun (\%) } \\
\cline { 2 - 6 } Stasiun & Ea & Th & Cs & Cr & Hu \\
\hline P1 & $3.21 \%$ & $10.22 \%$ & $14.73 \%$ & $4.73 \%$ & 0 \\
P2 & $3.03 \%$ & $13.44 \%$ & $12.87 \%$ & $9.46 \%$ & 0 \\
B1 & $2.27 \%$ & $11.69 \%$ & $10.41 \%$ & 0 & $5.11 \%$ \\
B2 & $1.13 \%$ & $10.60 \%$ & $9.46 \%$ & 0 & $3.78 \%$ \\
\hline
\end{tabular}

Keterangan: $\mathrm{Ea}=$ Enhalus acoroides $; \mathrm{Th}=$ Thalasiia hemprichii $; \mathrm{Cs}=$ Cymodocea serrulata; $\mathrm{Hu}=$ Halodule uninervis $; \mathrm{CR}=$ Cymodocea rotundata 


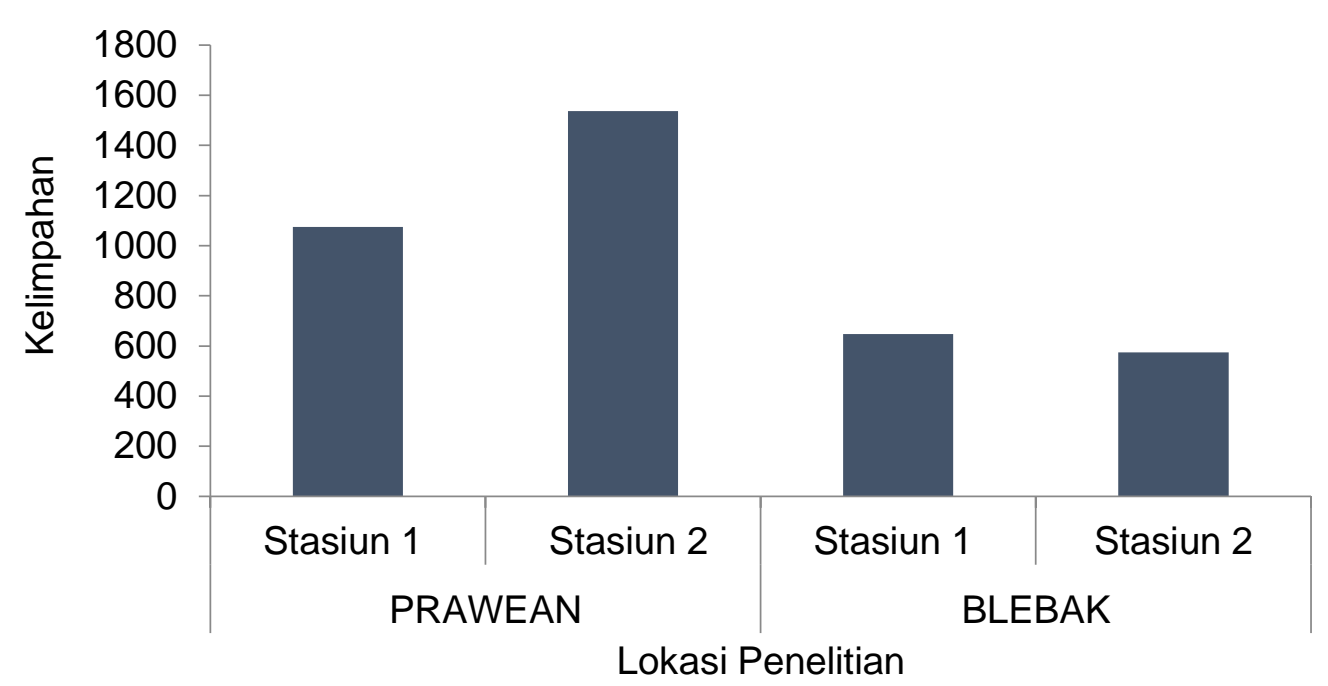

Gambar 3. Grafik Kelimpahan Larva Ikan di Pantai Prawean dan Pantai Blebak

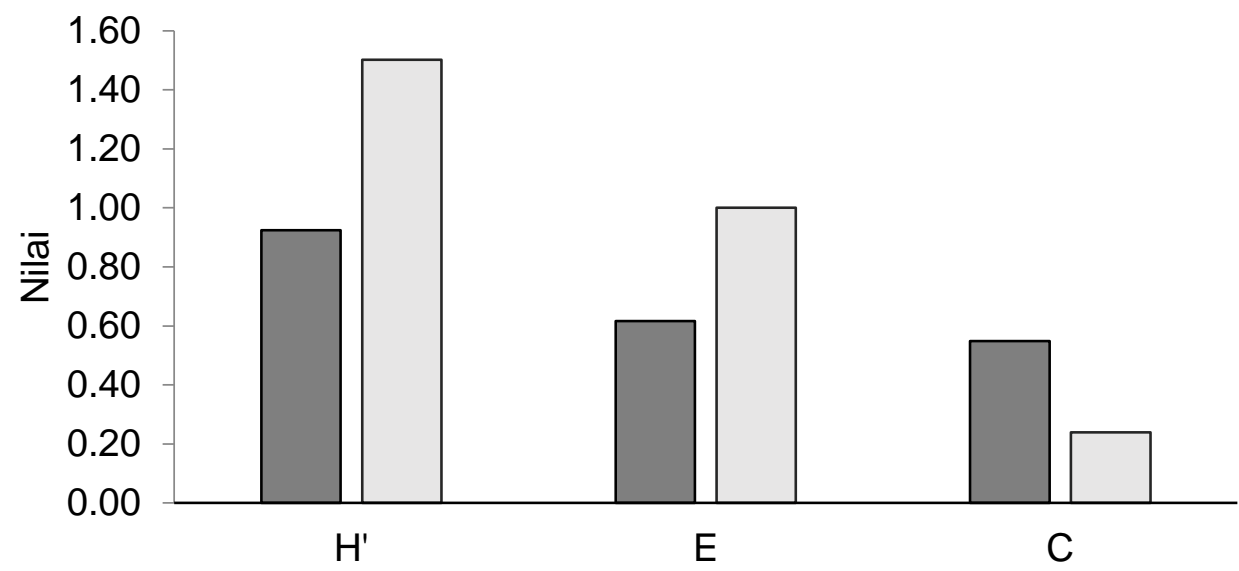

口 Stasiun $1 \quad \square$ Stasiun 2

Gambar 4. Grafik Indeks Keanekaragaman ( $\left.\mathrm{H}^{\prime}\right)$, Indeks Keseragaman (E) dan Indeks Dominasi (C) pada Pantai Prawean

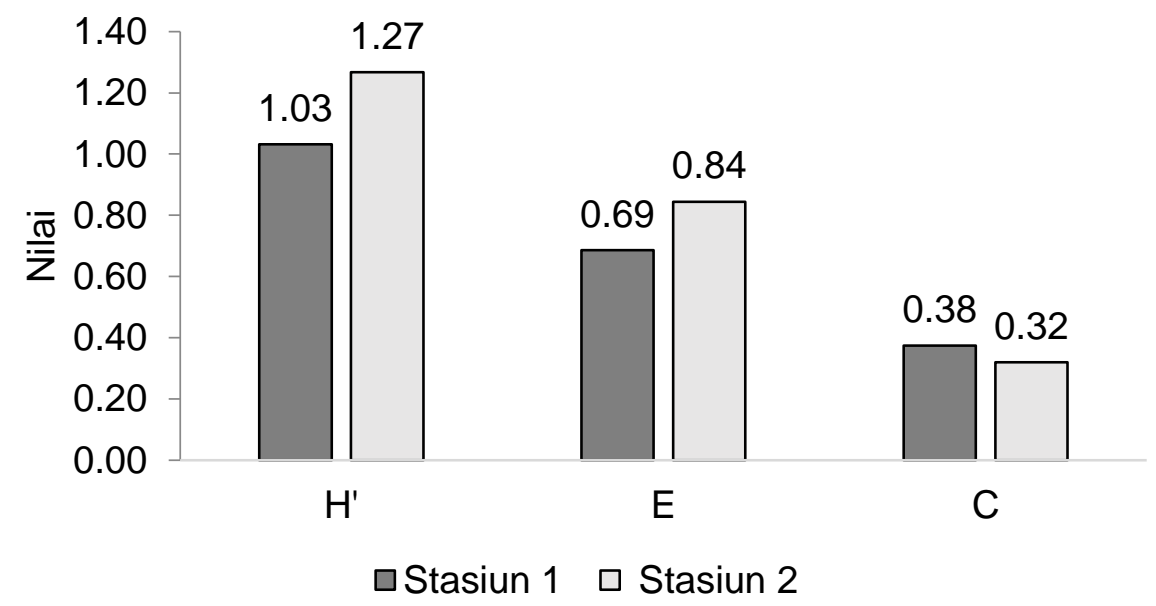

Gambar 5. Grafik Indeks Keanekaragaman $\left(H^{\prime}\right)$, Indeks Keseragaman (E) dan Indeks Dominasi (C) pada Pantai Blebak. 
sedang) dan pada stasiun 2 memiliki hasil 1,267 (keanekaragaman sedang). Nilai indeks keseragaman (E) pada Pantai Prawean stasiun 1 memilki hasil 0,615 (keseragaman sedang) dan pada stasiun 2 memiliki hasil 1,0 (keseragaman tinggi), untuk hasil dari Pantai Blebak stasiun 1 memperoleh 0,686 (keseragaman sedang) dan 0,843 (keseragaman sedang) pada stasiun 2. Nilai indeks dominasi $(C)$ untuk lokasi pengamatan Pantai Prawean stasiun 1 memperoleh hasil 0,548 (terdapat jenis mendominasi) dan 0,238 (tidak mendominasi) pada stasiun 2, untuk hasil indeks dominasi Pantai Blebak stasiun 1 memperoleh hasil 0,375 (tidak mendominasi) dan 0,320 (tidak mendominasi) pada stasiun 2. Selengkapnya disajikan pada (Gambar 4 dan Gambar 5).

Rapatnya vegetasi lamun menyebabkan lambatnya pergerakan air yang disebabkan oleh arus dan gelombang sehingga menjadikan perairan di bawahnya menjadi tenang. Beberapa mysid, hirdomedusa dan juvenil ikan, banyak ditemukan pada daerah tersebut. Karena adanya keadaan ini, maka mineral dan partikel organik terlarut di dalam air akan lebih mudah terperangkap dan mengendap di padang lamun. Dengan adanya fungsi lamun sebagai sediment trap maka beberapa jenis fauna akan melakukan kegiatan yang lebih efektif. Hasil analisis uji korelasi hubungan kelimpahan larva ikan dan kerapatan lamun diketahui memiliki persamaan linier $y=27.326 x-508.34$ dengan regresi $R^{2}=0.937$ (Gambar 6) dapat diketahui hasil tersebut menunjukan hubungan positif antara kelimpahan larva ikan dan penutupan lamun, oleh sebab itu korelasi antara kelimpahan larva ikan dan penutupan lamun menunjukkan bahwa semakin besar presentase penutupan lamun, semakin banyak juga larva ikan yang tertangkap di lokasi tersebut, hal ini diperkuat oleh penelitian yang dilakukan Ernanto, Agustriani \& Aryawaty (2010), bila nilai R $=0,701-1,000$ maka hubungan korelasi antara variabel $\mathrm{x}$ (kerapatan lamun) dengan variabel $\mathrm{y}$ (kelimpahan larva ikan) adalah dekat. Komposisi famili dan kelimpahan larva ikan yang diperoleh pada setiap stasiun yang berdasarkan tingkat kerapatan lamun menunjukkan adanya perbedaan. Menurut Subiyanto et al. (2008), diduga perbedaan komposisi jenis larva ikan berkaitan dengan migrasi ikan mencari kondisi lingkungan yang sesuai dengan kebutuhan makanan untuk pertumbuhan.

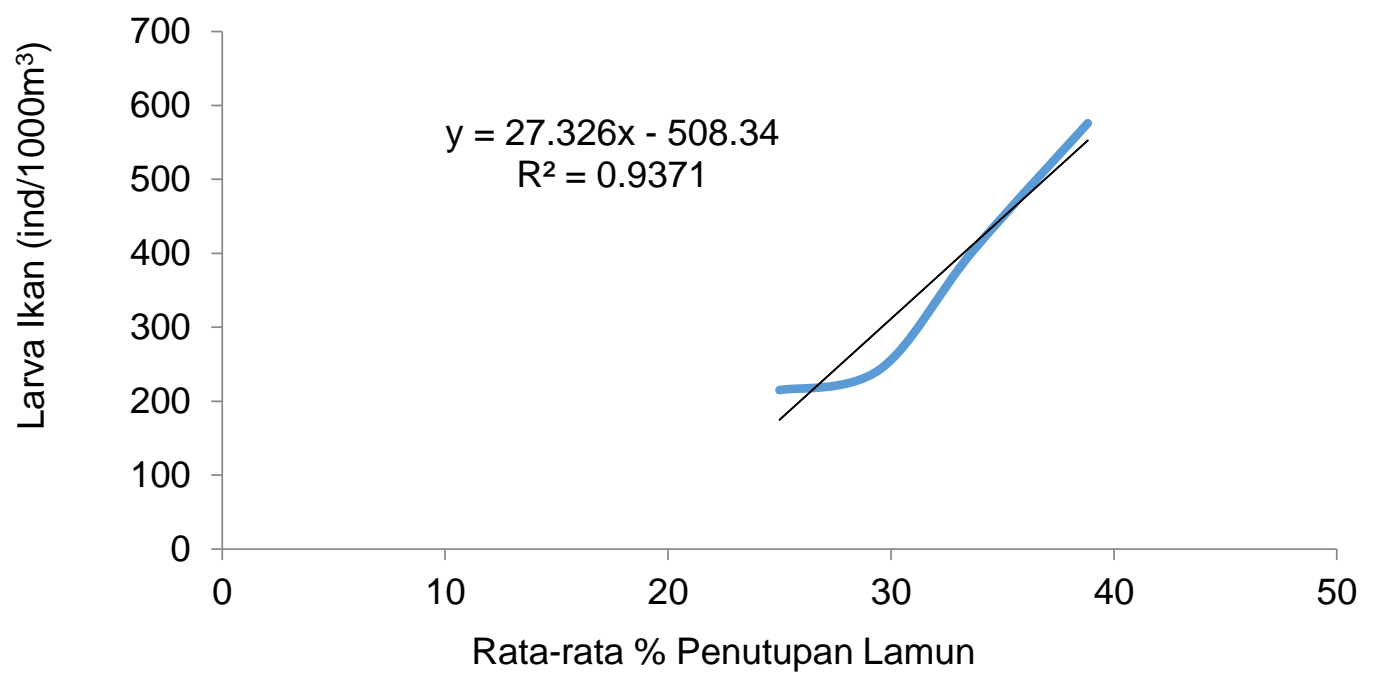

Gambar 6. Hubungan Kelimpahan larva ikan dan Kerapatan lamun

\section{KESIMPULAN}

Berdasarkan hasil penelitian, telah ditemukan larva ikan sebanyak 8 famili, diantaranya adalah Nemipteridae, Lutjanidae, Ambassidae, Sphyraenidae, Clupeidae, Bothidae, Chanidae, dan Monacanthidae. Kelimpahan larva ikan pada lokasi pengamatan Pantai Prawean lebih tinggi dibandingkan lokasi pengamatan Pantai Blebak. Hasil analisis uji korelasi hubungan kelimpahan larva ikan dan kerapatan lamun diketahui menunjukan hubungan positif dengan nilai $y=27.326 x-508.34$ dengan regresi $R 2=0.937$, semakin besar presentase penutupan lamun, semakin banyak juga larva ikan yang tertangkap di lokasi tersebut. 


\section{DAFTAR PUSTAKA}

Danovaro, R.C., Gambi, C. \& Mirto, S. 2002. Meiofaunal Production and Energy Transfer Efficienvcy In A Seagrass Posidonia Oceanica Bed In The Wsetern Mediteranian. Marine Ecology Progress Series, 234:95-104.

Ernanto, R., Agustriani, F., \& Aryawaty, R. 2010. Struktur komunitas gastropoda pada ekosistem mangrove di muara Sungai Batang Ogan Komering llir Sumatera Selatan. Maspari Journal, 1(1):73-78.

Hidayaturrohmah, F., Sulardiono, B. \&Taufani, W. T. 2018. Kelimpahan larva ikan berdasarkan fase bulan di padang lamun Pantai Prawen, Jepara. Management of Aquatic Resources Journal, 7(4):431-439.

Kiswara, W., Moosa, M.K. \& Hutomo, M. 1994. Struktur Komunitas Lamun di Pantai Selatan Lombok dan Kondisi Lingkungannya. Pusat Penelitian dan Pengembangan Oseanologi LIPI, 15-33.

Leis, J.M. \& Rennis, D.S. 1983. The Larvae of Indo-Pacific Coral Reef Fishes. New South Wales University Press and University of Hawaii Press. Hawaii and Australia.

Nyabakken, J.W. 1992. Biologi Laut Suatu Pendekatan Ekologis. PT. Gramedia, Jakarta.

Olli, A.H. 2003. Kajian Faktor Fisik yang Mempengaruhi Distribusi Ichtyoplankton (Awal Dur Hidup Ikan). Pengantar Falsafah Sains.

Rappe, R.A. 2010. Struktur Komunitas Ikan pada Padang Lamun yang Berbeda Di Pulau Barrang Lompo. Jurnal IImu dan Teknologi Kelautan Tropis, 2(2):63.

Rinaldi, R.K., Widyorini, N. \& Purnomo, P.W. 2018. Komposisi Larva Ikan di Kawasan Konservasi Mangrove Dusun Senik, Desa Bedono, Kecamatan Sayung, Demak. Journal of Management of Aquatic Resources, 6(2):147-155.

Riniatsih, I. 2016. Distribusi Jenis Lamun Dihubungkan dengan Sebaran Nutrien Perairan di Padang Lamun Teluk Awur Jepara. Jurnal Kelautan Tropis, 19(2):101-107.

Saraswati, A., Sholichin., Hartoko, A. \& Suharti, S.R. 2016. Hubungan Kerapatan Lamun Dengan Kelimpahan Larva Ikan Di Pulau Pramuka, Kepulauan Seribu Jakarta. Management of Aquatic Resources Journal, 5(3):111-118.

Smith-Vaniz, W.F. \& Rose, J.M. 2012. Adelptremus leptus, a New Genus and Species of Sabertooth Blenny from the Red Sea (Teleostei: Blennidae: Nemaphini). Zootaxa, 3249:39-46.

Subiyanto, M.F., Herimawan \& Rudiyanti, S. 2008. The Habit Alimentaires Analysis (Food Habit) of Hypoatherina sp. Larvae in East Pelawangan Segara Anakan Cilacap. Saintek Perikanan: Indonesian Journal of Fisheries Science and Technology, 3(2):82-86.

Suryabrata, S. 1992. Metodologi Penelitian. CV. Rajawali. Jakarta.

Syukur, A., Wardiatno, Y., Muchsin, I. \& Kamal, M.M. 2014. Status Trofik Ikan yang Berasosiasi dengan Lamun (Seagrass) di Tanjung Luar Lombok Timur. Jurnal Biologi Tropis, 14(2):162170. 